\title{
Effects of Irrigation Methods and Water Regimes on Occurrences of Cucumo-And Poty- Viruses in Watermelon
}

\author{
Kehinde Titilope Kareem \\ Grain Legumes Improvement Programme, Institute of Agricultural Research and Training, \\ Obafemi Awolowo University, Ibadan, Nigeria。 \\ Adebayo Olubukola Oke \\ Land and Water Resource Management Programme, Institute of Agricultural Research and \\ Training, Obafemi Awolowo University, Ibadan, Nigeria, \\ Kayode Stephen Are \\ Land and Water Resource Management Programme, Institute of Agricultural Research and \\ Training, Obafemi Awolowo University, Ibadan, Nigeria \\ Oluwafolake Adenike Akinbode \\ Maize Improvement Programme for Southern Ecologies, Institute of Agricultural Research \\ and Training, Obafemi Awolowo University, Ibadan, Nigeria. \\ Ayodele Olumide Adelana \\ Land and Water Resource Management Programme, Institute of Agricultural Research and \\ Training, Obafemi Awolowo University, Ibadan, Nigeria \\ Received: July 10, 2016 \\ Accepted: July 25, 2016 \\ Published: August 30, 2016 \\ doi:10.5296/jas.v4i3.9715 \\ URL: http://dx.doi.org/10.5296/jas.v4i3.9715
}

\begin{abstract}
The response of watermelon to Cucumber mosaic virus (CMV) and Watermelon mosaic virus (WMV) under different irrigation methods and water regimes (WRs) was investigated. Watermelon varieties; Kaolak and Sugar baby were irrigated using either sprinkler or basin method of application at 50\%, 75\% and 100\% WRs during the dry season. Results showed that at 3 and 5 weeks after planting (WAP) total irrigation at $100 \%$ water regime $\left(\mathrm{WR}_{100}\right)$ produced the tallest plants with basin irrigation. Mean values of $15.68 \mathrm{~cm}$ and $15.85 \mathrm{~cm}$ were obtained from Kaolak and Sugar baby respectively with basin irrigation at $\mathrm{WR}_{100}$. However, irrigation at $\mathrm{WR}_{50}$ produced shorter plants with fewer leaves. Complete yield loss was
\end{abstract}


recorded on the field due to severe virus infection. Mixed virus infections were evident in some of the treatments but basin irrigation at $\mathrm{WR}_{75}$ and $\mathrm{WR}_{100}$ had no mix infection of CMV and WMV. Also, varieties were not susceptible to CMV infection at $\mathrm{WR}_{75}$ and $\mathrm{WR}_{100}$ when basin irrigation was used. However, the most severe CMV infection occurred in Sugar baby at $\mathrm{WR}_{50}$ using sprinkler irrigation with virus titre of 1.285 . The two varieties were susceptible to WMV irrespective of the irrigation method or WR. The highest WMV titre was 2.88 obtained from Sugar baby at $\mathrm{WR}_{50}$. Total irrigation produced plants with good agronomic parameters compared with deficit irrigation. However, complete yield loss was recorded as a result of either single or double virus infections. Therefore, virus prevention and breeding for virus resistance are best approaches for the control of plant viruses.

Key words: Basin, irrigation, sprinkler, watermelon, water regime, virus

\section{Introduction}

Watermelon is one of the major cucurbit crops which thrive in different parts of the world especially in tropical and subtropical regions. Cultivation of watermelon requires adequate supply of water although; the crop is not regarded as high water demand crop (FAOSTAT, 2001). In Nigeria, this crop command higher prices than the local non-exotic crops especially in dry season. The challenge of pest and disease infestation could however reduce the projected revenue from cultivation even under irrigation which is an extra input into production costs. Its cultivation is hampered by numerous viral diseases that often cause economic losses in most production areas (Gaba et al., 2004; Papayiannis et al., 2005). The cucurbit crops are susceptible to at least 35 viruses (Papayiannis et al., 2005), among which Cucumber mosaic virus (CMV), Cucumber green mottle mosaic virus (CGMMV), and Watermelon mosaic virus (WMV) are the most damaging viruses in watermelon.

The occurrence of more than one virus species in a single plant is not uncommon in cultivated and native plant species. A mixed virus infection may lead to greater disease severity than individual viral components and this is sometimes referred to as a synergistic disease (Murphy and Bowen, 2006). Mixed infections can also modify viral traits such as host range (Hacker and Fowler, 2000; García-Cano et al., 2006), transmission rate (Wintermantel et al., 2008), cellular tropism (Wege and Siegmund, 2007), or titer. Most studies have focused on synergistic diseases caused by two ssDNA virus or ssRNA; particularly by a Potyvirus and other ssRNA virus. In most instances, the titer of the non-potyvirus increases while that of the potyvirus is not altered (Wang et al., 2002; Murphy and Bowen, 2006; Taiwo et al., 2007). This enhancement has been explained by potyvirus HC-Pro-mediated RNA silencing suppression (Valli et al., 2006). Nevertheless these interactions not always produce synergistic diseases (Wang et al., 2004; Untiveros et al., 2007), and depending on the particular combination of virus species, accumulation of the counterpart can also decrease (Kokkinos and Clark, 2006). Infections of cucurbit species by either potyviruses such as Zuchinni yellow mosaic virus (ZYMV) or Watermelon mosaic virus (WMV) or by CMV are very common and cause considerable damage worldwide in severe epidemics in cucurbit fields, either in single or double infections (Wang et al., 2002).

Cucumber mosaic virus has a worldwide distribution and a very wide host range. It has been known that the virus has the widest host range of any known plant virus (191 hosts in 40 
families) (Gallitelli, 2000). It can be transmitted from plant to plant both mechanically by sap and by aphids in a stylet-borne manner (Palukaitis and Garcia-Arenal, 2003). Viruses in the genus potyvirus [e.g., Papaya ringspot virus (PRSV), Watermelon mosaic virus (WMV) and Zucchini yellow mosaic virus (ZYMV)] are transmitted by aphids in a nonpersistent manner and are considered a constant threat to cucurbit crops (Guner and Whener, 2008). With growing interest in cultivation of the crop outside the northern part of Nigeria which range between derived to sahel savannah ecology, there is need to understand the behavior of viruses associated with the growing of the crop.

The extent of manifestation of potyvirus (watermelon mosaic virus) and cucumovirus (cucumber mosaic virus) or their synergistic interactions under total irrigation, supplemental or deficit irrigation have not being well investigated. This work was to investigate the impact of irrigation type and water regimes on the growth of watermelon as well as on the titres of Watermelon mosaic virus and Cucumber mosaic virus in Ibadan which is in the Humid, Sub-Humid agro ecology.

\section{Materials and Methods}

\subsection{Study Location and Scope}

This study was carried out in one of the experimental fields of the Institute of Agricultural Research and Training, Moor Plantation Ibadan, Nigeria. The field $\left(7^{0} 38^{\prime} \mathrm{E}, 3^{0} 84^{\prime} \mathrm{N}\right.$ and 174.3 $\mathrm{m}$ above sea level) is in the Humid, Sub-humid Agro Ecological Zone of Nigeria. The experiment was conducted during the dry season (between December and March, 2013) when evapotranspiration exceeds precipitation (Oke et al, 2011).

Two varieties of watermelon; Kaolak and Sugar baby were obtained from a Farmer's Support Seed shop at, Ibadan, Oyo State, Nigeria. The watermelon was raised during the dry season when crop water requirement was supplied through irrigation. Two irrigation methods and three levels of irrigation were employed.

\subsection{Soil and Water Characterization}

The soil samples were taken for soil test while core samples were also taken at $0-15 \mathrm{~cm}$ and $15-30 \mathrm{~cm}$ for soil physical characteristics examination including determination of available water of the field.

\subsection{Experimental Design}

The seeds were planted on $24^{\text {th }}$ December, 2013 during dry season. Two irrigation treatments (Sprinkler and Basin) were the main plots while the three (3) irrigation water regimes were sub plots. The water regimes were based on Consumptive Use $\left(\mathrm{C}_{\mathrm{u}}\right)$ computed from Reference Evapotranspiration $\left(\mathrm{ET}_{\mathrm{o}}\right)$ and Crop Coefficient $\left(\mathrm{K}_{\mathrm{c}}\right)$ for Watermelon. The CROPWAT 8.0 was used in computing the $\mathrm{ET}_{\mathrm{o}}$ while the $\mathrm{Cu}$ was computed from Equation 1.

$$
C_{u}=K_{c} * E T_{o}
$$

Relative to $\mathrm{C}_{\mathrm{u}}$, the water regimes are $50 \%\left(\mathrm{WR}_{50}\right), 75 \%\left(\mathrm{WR}_{75}\right)$ and $100 \%\left(\mathrm{WR}_{100}\right)$. The Net Irrigation (NIR) water applied within a developmental stage was obtained for each of the water regime using equation 2. 
NIR $=$ WR $x$ no of days within a stage

Two watermelon varieties V1 (Kaolak) and V2 (Sugar baby) were investigated. The field was arranged in Split Plot with 3 replications. With each plot size of $3 \mathrm{~m} \times 3 \mathrm{~m}$, the planting spacing was $1 \mathrm{~m} \times 0.5 \mathrm{~m}$ while a space of $2 \mathrm{~m}$ was set between plots. A space of $4 \mathrm{~m}$ was imposed between irrigation types. Basic agronomic management practices were carried out.

\subsection{Agronomic and Irrigation Data}

The basin irrigation was accomplished by creating bunds $(25 \mathrm{~cm})$ around the basin plots and the irrigated water was released into the plot using graduated bucket. Sprinkler treatment was done using 10 litres size watering can with which computed volume of water was applied. To evaluate the differences and impacts of WRs on the performance of the crop varieties, plant height, number of leaves were taken at three Weeks after Planting (WAP) and 5 WAP on tagged plants per plot. Numbers of flowers and fruits were also counted from the tagged plants. Volume of water used at the various regimes were noted

\subsection{Determination of the Effect of Irrigation Methods and Water Regimes on Virus Titres}

Leaf samples were plucked from the same position from the tagged plants that received the different treatments and they were kept in envelopes and transported to the laboratory in an ice box. The determination of the presence of single and mixed infections of Cucumber mosaic virus (CMV), a cucumovirus and Watermelon mosaic virus (WMV), a potyvirus was carried out by using enzyme-linked immunosorbent assay (ELISA) according to the manufacturer's instruction (Agdia Inc. Elk. IN, USA) and as described by Taiwo et al. (2007). The absorbance of the optical density (OD) at $405 \mathrm{~nm}$ was measured in an ELISA plate reader (ELx800). Absorbance values were considered positive when the OD ratio of infected samples/negative contro (healthy plant)l is greater than 2 .

\subsection{Statistical Analysis}

Data were subjected to analysis of variance with levels of significance defined by the Least Square Difference (LSD). Means from the interactions of the treatments (irrigation, irrigation regimes and varieties) were separated using Duncan Multiple Range Test (DMRT) at $\mathrm{P} \leq 0.05$. The GENSTAT and Statistical Package for Social Scientists (SPSS 16.0) were used to analyse the data obtained.

\section{Results}

\subsection{Water use and crop coefficient of Watermelon}

Crop developmental stages and corresponding crop coefficient $\left(\mathrm{K}_{\mathrm{c}}\right)$ are shown in Figure 1. Development stages of watermelon are based on Richard et al. (1998). Following the evapotranspiration characteristics of the production location, the variation in water need is reflected in the crop coefficient $\left(\mathrm{K}_{\mathrm{c}}\right)$. The $\mathrm{K}_{\mathrm{c}}$ shows the fraction of $\mathrm{ET}_{\mathrm{o}}$ that must be met. The crop coefficient of 1.0 during the flowering and fruit set and 0.8 during the fruit and maturity show how much water was used during these critical stages. Thus, the water applied during production is presented in Table 1. The NIR which is the total irrigation water applied based 
on the $\mathrm{ET}_{\mathrm{c}}$ were $228.4 \mathrm{~mm}, 319.8 \mathrm{~mm}$ and $456.9 \mathrm{~mm}$ for $\mathrm{WR}_{50}, \mathrm{WR}_{75}$ and $\mathrm{WR}_{100}$ respectively. Virus infections were noticed from 7 - 8 WAP during fruiting. The fruits aborted and rotted leading to total yield loss.

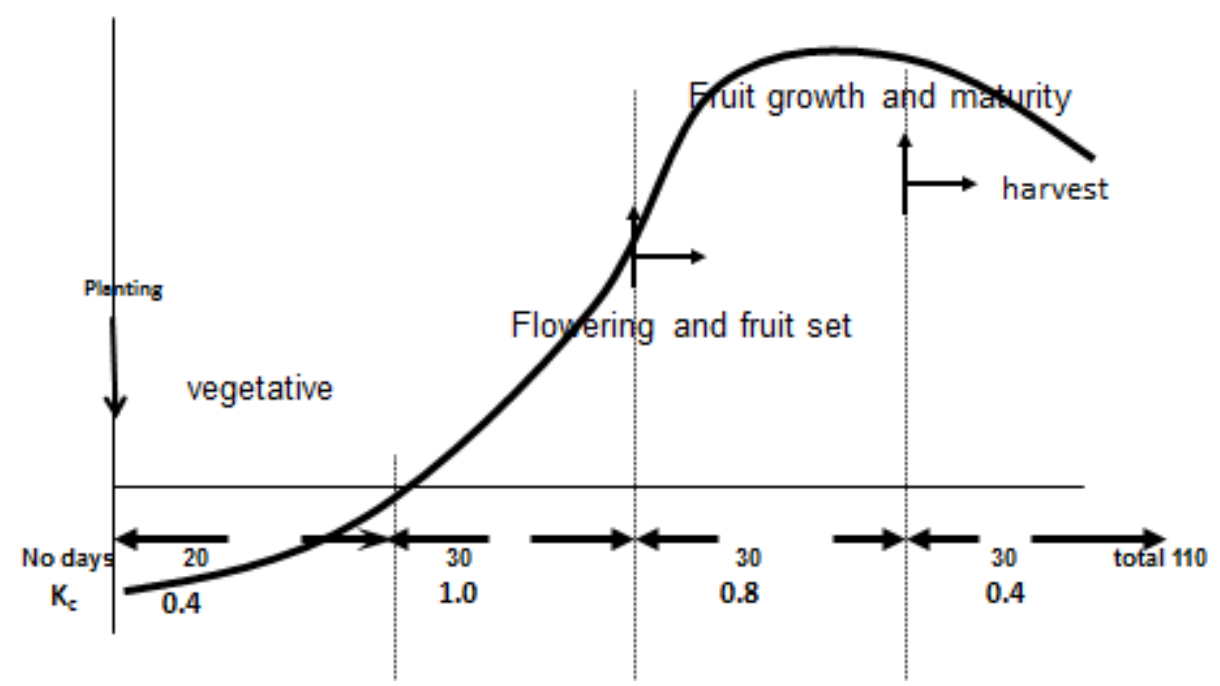

Figure 1. The Watermelon Crop Development Stages

Table 1. Water application for water melon growth stages

\begin{tabular}{lllllllllll}
\hline Crop Stages & Days & $\boldsymbol{K}_{\boldsymbol{c}}$ & $\boldsymbol{E t}_{\boldsymbol{o}}$ & $\boldsymbol{E t}_{\boldsymbol{c}}$ & \multicolumn{2}{l}{$\begin{array}{l}\text { Water Regimes } \\
\boldsymbol{W R}(\boldsymbol{m m})\end{array}$} & \multicolumn{3}{l}{$\begin{array}{l}\text { Net Irrigation } \\
\text { NIR (mm) }\end{array}$} \\
\hline Stages & & & & & $W R_{50}$ & $W R_{75}$ & $W R_{100}$ & $W R_{50}$ & $W R_{75}$ & $W_{100}$ \\
Initial & 20 & 0.4 & 5.3 & 2.1 & 1.1 & 1.5 & 2.1 & 21.2 & 29.7 & 42.4 \\
Development & 30 & 1.0 & 7.1 & 7.1 & 3.6 & 5.0 & 7.1 & 106.5 & 149.1 & 213.0 \\
Mid & 30 & 0.8 & 5.7 & 4.3 & 2.1 & 3.0 & 4.3 & 64.1 & 89.8 & 128.3 \\
Late & 30 & 0.4 & 6.1 & 2.4 & 1.2 & 1.7 & 2.4 & 36.6 & 51.2 & 73.2 \\
TOTAL & 110 & & & & & & & 228.4 & 319.8 & 456.9 \\
\hline
\end{tabular}

$\mathrm{K}_{\mathrm{c}}=$ Crop Coefficient; $\quad \mathrm{Et}_{\mathrm{o}}=$ Reference Evapotranspiration; $\mathrm{Et}_{\mathrm{c}}=$ Consumptive Use or

Crop Water Requirement

\subsection{Effect of Irrigation Type, Irrigation Regimes and Variety On Growth of Watermelon}

Table 2 presents the mean values of growth data, CMV and WMV at $3 \mathrm{WAP}$ and 5WAP. It was observed that variety does not impact any significant difference in the plant height at 3WAP while the plant height of $15.2 \mathrm{~cm}$ recorded from Kaolak was significantly difference from what was observed at 5WAP $(13.8 \mathrm{~cm})$ posted by Baby Sugar variety. No significant difference was recorded in the number of leaves at 3WAP and 5WAP irrespective of variety. The incidence of CMV was not also significant in the two varieties even though the opposite was observed in WMV.

Furthermore, the impact of irrigation type did not produce any significance difference in the number of leaves at $3 \mathrm{WAP}$ or $5 \mathrm{WAP}$ whereas at $3 \mathrm{WAP}$, plant height from Basin irrigation was 
observed to be significantly higher than plant height from 5WAP. This implies that the impact of method may not be critical on the growth of watermelon beyond the initial few weeks of crop life. Although, the level of CMV and WMV were significantly difference across the irrigation method employed. Sprinkler irrigation poses significantly higher level of virus incidence with CMV and WMV being 1.0 and 1.3 respectively. From Table 2 also, it was observed that irrigation water regime did not significantly affect growth parameters at $\mathrm{P}$ $<0.05$. However, significant differences were noticed at higher level of probability. Although, the plant heights and number of leaves at $3 \mathrm{WAP}$ and $5 \mathrm{WAP}$ were better at $\mathrm{WR}_{75}$ and best at $\mathrm{WR}_{100}$, the reverse was the case with the virus incidence which was worst in least level of irrigation $\left(\mathrm{WR}_{50}\right)$. At higher irrigation regime $\left(\mathrm{WR}_{100}\right.$ or $\left.\mathrm{WR}_{75}\right)$, when more water was supplied, virus incidences were significantly lower $(\mathrm{p}<0.001)$.

Table 2. Analysis of Variance of the Varieties, Irrigation Methods and Irrigation Regimes

\begin{tabular}{|c|c|c|c|c|c|c|}
\hline Treatment & $\begin{array}{l}\text { Plant Height } \\
3 \text { WAP }(\mathrm{cm})\end{array}$ & $\begin{array}{l}\text { Plant } \\
\text { Height } \\
\text { 5WAP }(\mathrm{cm})\end{array}$ & $\begin{array}{l}\text { No of leaves } \\
3 \text { WAP }\end{array}$ & $\begin{array}{l}\text { No of leaves } \\
5 \mathrm{WAP}\end{array}$ & $\mathrm{CMV}$ & WMV \\
\hline \multicolumn{7}{|l|}{ Varieties } \\
\hline Kaolak & 12.4 & 15.2 & 11.8 & 39.7 & 0.82 & 0.81 \\
\hline Baby Sugar & 12.2 & 13.8 & 11.4 & 38.3 & 0.86 & 1.44 \\
\hline LSD & $1.28 \mathrm{~ns}$ & $1.15^{*}$ & $0.78 \mathrm{~ns}$ & $4.92 \mathrm{~ns}$ & $0.09 \mathrm{~ns}$ & $0.21 * * *$ \\
\hline \multicolumn{7}{|l|}{ Irrigation } \\
\hline Sprinkler & 11.6 & 14.5 & 11.4 & 37.7 & 1.0 & 1.30 \\
\hline Basin & 13.0 & 14.5 & 11.8 & 40.4 & 0.68 & 0.95 \\
\hline LSD & $1.28 *$ & $1.15 \mathrm{~ns}$ & $0.78 \mathrm{~ns}$ & $4.92 \mathrm{~ns}$ & $0.09 * * *$ & $0.21 * *$ \\
\hline \multicolumn{7}{|l|}{ Irrigation Regime } \\
\hline $50 \%$ & 10.9 & 13.5 & 11.1 & 29.1 & 1.07 & 1.59 \\
\hline $75 \%$ & 11.9 & 14.0 & 11.5 & 38.6 & 0.74 & 1.08 \\
\hline $100 \%$ & 14.1 & 16.0 & 12.1 & 49.4 & 0.72 & 0.71 \\
\hline LSD & $1.57 * * *$ & $1.40 * *$ & $0.96 \mathrm{~ns}$ & $6.03 * *$ & $0.12 * * *$ & $0.25 * * *$ \\
\hline
\end{tabular}


applied in basin produced the tallest plant with average values of $15.68 \mathrm{~cm}$ and $15.85 \mathrm{~cm}$ for Kaolak and Sugar baby respectively. This was followed by sprinkler irrigation of Sugar baby at $\mathrm{WR}_{100}$ having an average value of $14.5 \mathrm{~cm}$. The shortest plants were produced at $\mathrm{WR}_{50}$ using basin irrigation with average values of $9.67 \mathrm{~cm}$ and $9.92 \mathrm{~cm}$ for Kaolak and Sugar baby respectively (Table 3). At $5 \mathrm{WAP}$, it was observed that the highest significant $(\mathrm{P} \leq 0.05)$ plant height values of $15.67 \mathrm{~cm}$ and $16.67 \mathrm{~cm}$ were obtained from Sugar baby and Kaolak irrigated with $\mathrm{WR}_{100}$ in basin irrigation. These values were not significantly different from $15.42 \mathrm{~cm}$ obtained from Sugar baby irrigated at $\mathrm{WR}_{75}$ using basin (Table 3).

The number of leaves at 3 WAP revealed that Sugar baby and Kaolak that received $\mathrm{WR}_{100}$ using basin produced the highest mean number of leaves with values of 12.75 and 12.83 respectively while the least number of leaves (9.92) was obtained from Kaolak when irrigated at $\mathrm{WR}_{50}$ using basin (Table 2). Mean number of leaves at 5 WAP ranged from 23.75 to 55.75. Irrigation at $\mathrm{WR}_{50}$ led to the formation of very few leaves by the two varieties while irrigation with basin at $\mathrm{WR}_{100}$ led to the formation of more leaves by Sugar baby (Table 2). However, no significant difference was observed in the number of leaves at 5WAP in Basin or Sprinkler irrigation at $\mathrm{WR}_{75}$.

Table 3. Interaction of different irrigation regimes, irrigation type and varieties on plant height and number of leaves

\begin{tabular}{|c|c|c|c|c|c|c|}
\hline $\begin{array}{l}\text { Water } \\
\text { regime } \\
\text { (WR) }\end{array}$ & $\begin{array}{l}\text { Irrigation } \\
\text { type }\end{array}$ & Variety & 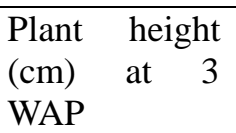 & $\begin{array}{l}\text { Plant height } \\
(\mathrm{cm}) \text { at } 5 \text { WAP }\end{array}$ & $\begin{array}{l}\text { No. of leaf at } 3 \\
\text { WAP }\end{array}$ & $\begin{array}{l}\text { No. of leaf at } 5 \\
\text { WAP }\end{array}$ \\
\hline \multirow{4}{*}{$50 \%$} & \multirow[t]{2}{*}{ basin } & 1 & $9.67 \mathrm{c}$ & 13.99ab & $9.92 b$ & $24.83 e$ \\
\hline & & 2 & $9.92 \mathrm{c}$ & $13.08 \mathrm{ab}$ & $11.50 \mathrm{ab}$ & $23.75 \mathrm{e}$ \\
\hline & \multirow[t]{2}{*}{ sprinkler } & 1 & $10.67 b c$ & $12.38 \mathrm{~b}$ & $11.17 \mathrm{ab}$ & $34.75 \mathrm{cde}$ \\
\hline & & 2 & $13.50 \mathrm{abc}$ & $14.41 \mathrm{ab}$ & $11.67 \mathrm{ab}$ & $33.25 \mathrm{de}$ \\
\hline \multirow{4}{*}{$75 \%$} & \multirow[t]{2}{*}{ basin } & 1 & $12.00 \mathrm{abc}$ & $14.25 \mathrm{ab}$ & $11.92 \mathrm{ab}$ & $39.67 \mathrm{bcd}$ \\
\hline & & 2 & $13.96 \mathrm{abc}$ & $15.42 \mathrm{a}$ & $11.58 \mathrm{ab}$ & $47.58 \mathrm{abc}$ \\
\hline & \multirow[t]{2}{*}{ sprinkler } & 1 & $10.67 b c$ & $12.73 b$ & $11.33 \mathrm{ab}$ & $33.42 \mathrm{de}$ \\
\hline & & 2 & $12.33 \mathrm{abc}$ & $12.31 \mathrm{~b}$ & $11.25 \mathrm{ab}$ & $33.58 \mathrm{de}$ \\
\hline & \multirow[t]{2}{*}{ basin } & 1 & $15.68 \mathrm{a}$ & $16.67 \mathrm{a}$ & $12.83 \mathrm{a}$ & 46.75abcd \\
\hline \multirow{3}{*}{$100 \%$} & & 2 & $15.85 \mathrm{a}$ & $15.67 \mathrm{a}$ & $12.75 \mathrm{a}$ & $55.75 \mathrm{a}$ \\
\hline & sprinkler & 1 & $13.50 \mathrm{abc}$ & $14.33 \mathrm{ab}$ & $11.17 \mathrm{ab}$ & 46.50abcd \\
\hline & & 2 & $14.50 \mathrm{ab}$ & $14.38 \mathrm{ab}$ & $11.67 \mathrm{ab}$ & $48.50 \mathrm{ab}$ \\
\hline
\end{tabular}

Mean values followed by the same letter are not significantly different at $5 \%$ level of probability according to Duncan's multiple range test. $1=$ Kaolak, $2=$ Sugar baby.

Although, insecticide (Cypermethrin) was applied at 2WAP and 5WAP, the manifestation of infestations in the field was quite high shortly after flowering (which was noticed from 8WAP). The yield could not be recorded because the plants experienced flower abortions and as a result very few plant stands were able to produce fruits. There was complete yield loss as the fruits produced were malformed and they could not develop to form normal fruits with 
the expected shapes and sizes of normal watermelon. Eventually all the fruits rotted away on the field. This problem, in relation to water regimes was observed to be worst in $\mathrm{WR}_{50}$ followed by $\mathrm{WR}_{75}$ and $\mathrm{WR}_{100}$. Nevertheless, the yield loss was total irrespective of the type of irrigation.

\subsection{Effect of different water regimes and irrigation types on virus titres}

The result on the effect of different water regimes and type of irrigation of the two varieties of watermelon showed that the plants had varying degree of susceptibility to CMV. Cucumber mosaic virus was present in all the treatments except at $\mathrm{WR}_{75}$ and $\mathrm{WR}_{100}$ using basin irrigation. However, Watermelon mosaic virus was present in all the treatments. Result on the reaction of watermelon varieties to mixed virus infections showed that there was no mixed infection of CMV and WMV when basin type of irrigation was used at $\mathrm{WR}_{75}$ and $\mathrm{WR}_{100}$ (Table 4).

Kaolak was not infected with $\mathrm{CMV}$ at $\mathrm{WR}_{75}$ and $\mathrm{WR}_{100}$ when basin method of application was used. Meanwhile, they were susceptible when sprinkler method was used and the titre values were 0.877 and 1.002 respectively. Kaolak was susceptible to WMV infection at all the WR levels. Although, the plants showed positive response to WMV at $\mathrm{WR}_{100}$ but the susceptibility was moderate, especially those that were irrigated with basin which had titres of 0.606 (Table 5).

The highest significant titre of CMV $(\mathrm{P} \leq 0.05)$ was observed in Sugar baby irrigated using sprinkler method at $\mathrm{WR}_{50}$ with a mean of 1.285 , followed by Sugar baby irrigated with basin at $\mathrm{WR}_{50}$ with an average value of 1.105 . Cucumber mosaic virus was absent at $\mathrm{WR}_{75}$ and $\mathrm{WR}_{100}$ using basin method of application and the titres were 0.419 and 0.455 respectively. With sprinkler irrigation at $\mathrm{WR}_{50}$, a significantly high WMV infection was recorded in Sugar baby with an average titre of 2.8795. Also, the effect of WMV on Sugar baby at $\mathrm{WR}_{50}$ using basin irrigation was pronounced with a mean titre of 1.9535. The WMV titre was equally high at $\mathrm{WR}_{75}$ using sprinkler irrigation (1.475) (Table 5).

There was enhancement of WMV titres in most of the treatments especially Sugar baby that received $\mathrm{WR}_{50}$ using sprinkler and basin irrigation with titres of 2.879 and 1.954 respectively. Nevertheless, the titres of CMV was also enhanced in few cases especially in Kaolak at $\mathrm{WR}_{50}$ with titres of 0.934 and 0.957 for basin and sprinkler methods respectively and also at $\mathrm{WR}_{100}$ using sprinkler method (1.002) (Table 5).

Table 4. Reaction of watermelon to single and mixed virus infections

\begin{tabular}{llllll}
\hline & & \multicolumn{3}{l}{ Single infection } & Mixed infection \\
\hline Water regime & Type of irrigation & Variety & CMV & WMV & CMV +WMV \\
\hline \multirow{3}{*}{$50 \%$} & Sprinkler & 1 & + & + & + \\
& & 2 & + & + & + \\
& Basin & 1 & + & + & + \\
& & 2 & + & + & + \\
$75 \%$ & 1 & + & + & + \\
& Sprinkler & 2 & + & + & + \\
& & 1 & - & + & - \\
& Basin & 2 & - & + & - \\
\hline
\end{tabular}




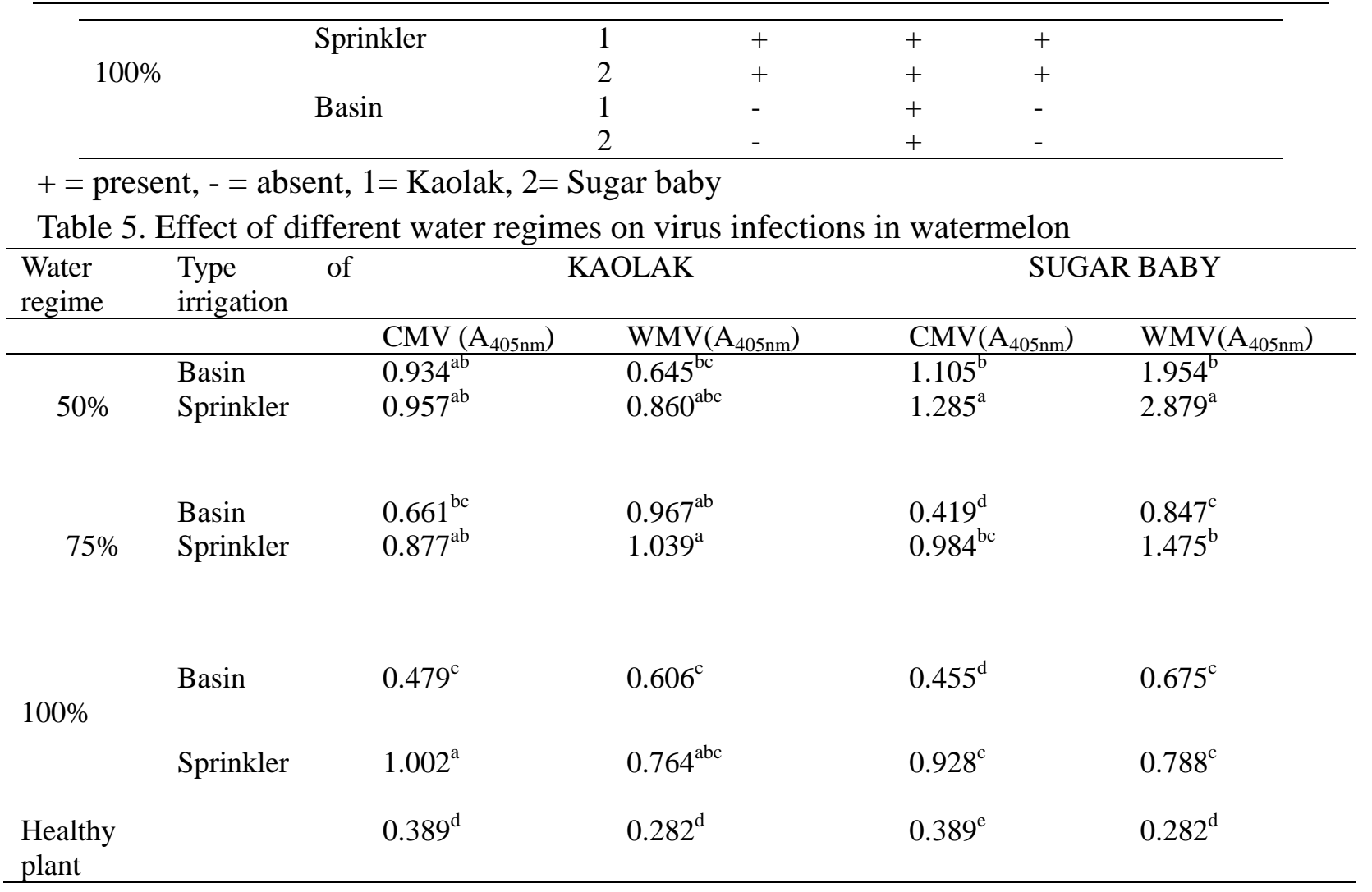

Mean values followed by the same letter are not significantly different at 5\% level of probability according to Duncan's multiple range test.

\section{Discussion}

This work reveals the importance of adequacy of water in production of watermelon. Water deficit contributed to disease spread which leads to yield loss. Plant growth was best when basin irrigation was at $\mathrm{WR}_{100}$ while $\mathrm{WR}_{50}$ led to poor growth of plants irrespective of irrigation type. The reason for this is because the $100 \%$ irrigation water supply was the optimum water requirement for watermelon, as a result, the plants were able to get enough water required for their physiological activities and this was translated to improved growth. Sani et al. (2008) reported that taller plants were produced when full consumptive use irrigation was used as compared to plants which received less amounts of water under the prevailing environmental conditions.

Complete yield loss of watermelon was reported in this experiment. The presence of viruses on the field could be responsible for the loss. Lin et al. (2012) reported that watermelon is prone to attack by several viruses which often results in destructive yield loss. Reduction in yield has also been observed by Gishumu et al. (2008).

This investigation revealed the natural occurrence of viruses (CMV and WMV) in watermelon plants grown on the field in the dry season of humid sub-humid ecology. This could be attributed to the fact that watermelon belongs to the family cucurbitacea, hence, its susceptibility to cucurbit viruses. The susceptibility of cucurbits to CMV and Potyviruses 
have been reported by many authors (Choi et al., 2000; Damicone et al., 2007; Lecoq, 2003).

Results on the effect of CMV on watermelon showed that both varieties were susceptible to CMV infection at WR5 50. This could be due to the fact that CMV is a common virus which causes disease of crops on the field in which watermelon is one of them. Roossinck (2002) reported that CMV is one of the most widely spread virus in the world infecting over 1,000 plant species belonging to more than 85 families. Also, Zitter and Murphy (2009) reported that Cucumber mosaic virus (CMV) is one of the important viruses in temperate, tropic and sub-tropic regions of the world which could cause crop losses on average of 10-20\%. Kaolak was not susceptible to $\mathrm{CMV}$ infection at $\mathrm{WR}_{75}$ and $\mathrm{WR}_{100}$ using basin irrigation. It can be explained that at optimum conditions of growth, Kaolak may show some levels of resistance to CMV infection. This statement corroborated the report of Jerry, 2016 which stated that all cucurbit species are susceptible to CMV but watermelon is rarely infected.

The two watermelon varieties were susceptible to WMV, the susceptibility might be due to the fact that Potyviruses are the major genus in the Potyviridae family and infect a broad range of host plants. It was reported by ICTV (2010) that potyviruses infect more than 2000 plant species of 550 genera and 81 families.

The ELISA result showed that both viruses were present in the leaves of the watermelon varieties. This implies that CMV and WMV were able to infect the varieties. Infections of cucurbit species by either potyviruses such as Zuchinni yellow mosaic virus (ZYMV) or Watermelon mosaic virus (WMV) or by CMV are very common and cause considerable damage worldwide in severe epidemics in cucurbit fields, either in single or double infections (Wang et al., 2002).

Virus diseases are one of the factors that affect plant growth and yield parameters. However, virus elimination can be achieved through proper management including supplying of required water during irrigation and control of insect vectors. The use of resistant cultivars and favourable climatic conditions are also important for plant growth. Therefore, disease resistance watermelon varieties and taking preventive cautions are suggested as means of economic control of diseases.

\section{References}

Choi, J. D., Choi, H. S., Kim, J. S., La, Y. J., \& Kim, K. S. (2000). Ultrastructural aspects of mixed infections with Watermelon mosaic potyvirus isolated from pumpkin and Cucumber green mottle mosaic tobamovirus from watermelon. Plant Pathol. J. 16, 216-221.

Damicone, J. P., Edelson, J. V., Sherwood, J. L., Myers, L. D. Motes, J. E. (2007). Effects of border crops and intercrops on control of cucurbit virus diseases. Plant Dis. 91, 509-516. http://dx.doi.org/ 10.1094/pdis-91-5-0509

FAOSTAT (2001). http://www.fao.org/nr/water/cropinfo_watermelon.html. Assessed $16^{\text {th }}$ August, 2016.

Gaba, V., Zelcer, A., \& Gal-On, A. (2004) Cucurbit biotechnology-the importance of virus resistance. In Vitro Cell Dev Biol Plant, 40, 346-358. http://dx.doi.org/10.1079/ivp2004554. 


\section{$\triangle$ Macrothink}

Journal of Agricultural Studies

ISSN 2166-0379

2016, Vol. 4, No. 3

Gallitelli, D. (2000). The ecology of cucumber mosaic virus and sustainable agriculture. Virus Research, 71, 9-21. PMID:11137158.

García-Cano, E., Resende, R. O., Fernández-Muñoz, R., \& Moriones, E. (2006). Synergistic interaction between Tomato chlorosis virus and Tomato spotted wilt virus results in breakdown of resistance in tomato. Phytopathology, 96, 1263-1269. http://dx.doi.org/10.1094/phyto-96-1263.

Gichimu, B. M., Owuor, B. O., \& Dida, M. M. (2008). Agronomic performance of three most popular commercial watermelon cultivars in kenya as Compared to one newly introduced cultivar And one local landrace grown on Dystric nitisols under sub- Humid tropical conditions Journal of Agricultural and Biological Science (Asian Research Publishing Network), 3(5\&6), $65-71$.

Guner, N., \& Whener, T.C. (2008). Proc. IXth EUCARPIA meeting Cucurbitaceae (Avignon, France). Overview of potyvirus resistance in watermelon, 445-451. (editted) ISBN 978-2-7380-1251-7.

Hacker, D. L., \& Fowler, B. C. (2000). Complementation of the host range restriction of southern Cowpea mosaic virus in bean by Southern bean mosaic virus.Virology, 266, 140-9. http://dx.doi.org/ 10.1006/viro.1999.0072.

ICTV. (2010). International Committe on taxanomy of viruses. Retrieved 02/06/10, from http://www.csiropedia.csiro.au/display/CSIROpedia/Potyvirus+taxonomy

Jerry, B. (2016). Viruses and other problems found in watermelon and Cantaloupe in Central Maryland. Weekly Crop update timely vegetable and agronomic crop info from university of Delaware Cooperative Extension. https:/agdev.anr.udel.edu.weeklycropupdate/p+2239 Assessed on $16^{\text {th }}$ August, 2016

Kokkinos, C. D., \& Clark, C. A. (2006). Interactions among Sweet potato chlorotic stunt virus and different potyviruses and potyvirus strains infecting sweetpotato in the United States. Plant Dis, 90, 1347-1352. http://dx.doi.org/10.1094/pd-90-1347.

Lecoq, H. (2003). Cucurbits. in: Virus and Virus-like Diseases of Major Crops in Developing Countries. G. Loebenstein and G. Thottapilly, eds., 665-687. Kluwer Academic Publishers, Dordrecht, The Netherlands.

Lin, C. Y., Ku, H. M, Chiang, Y. H., Ho, H.Y, Yu, T. A, \&. Jan, F. J. (2012). Development of transgenic watermelon resistant to Cucumber mosaic virus and Watermelon mosaic virus by using a single chimeric transgene construct. Transgenic Res., 21(5), 983-993. http://dx.doi.org/ 10.1007/s11248-011-9585-8.

Luis-Arteaga, M., Alvarez, J. M., Alonso-Prados, J. L., Bernal, J. J., Garcia-Arenal, F., Lavina, A., Batlle, A., \& Moriones, E. (1998). Occurrence, distribution, and relative incidence of mosaic viruses infecting field-grown melon in Spain. Plant Dis., 82, 979-982.

Murphy, J. F., \& Bowen, K. L. (2006). Synergistic disease in pepper caused by the mixed infection of Cucumber mosaic virus and Pepper mottle virus. Phytopathology, 96, 240-247. 
http://dx.doi.org/ 10.1094/phyto-96-0240.

Oke, A. O., Are, K. S., Oluwatosin, G. A., Adeyolanu, O. D., Dauda, T. O., \& Adelana A.O. (2011). Evaluation of water table dynamics for sustainable cultivation in wetlands. International Agrophysics, 25, 155-163.

Palukaitis, P., \& García-Arenal, F. (2003). Cucumoviruses. Adv Virus Res. 62, 241-323. http://dx.doi.org/ 10.1007/s00705-011-1216-4.

Papayiannis, L. C, Ioannou, N, Boubourakas, I. N., Dovas, C. I, Katis, N. I., \& Falk, B.W. (2005). Incidence of viruses infecting cucurbits in Cyprus. J Phytopathol, 153, 530-535. http://dx.doi.org/ 10.1111/j.1439-0434.2005.01015.x.

Richard, G. A., Luis, S. P., Dirk, R., \& Martin, S. (1998). Crop EvapotranspirationGuidelines for computing crop water requirements. FAO Irrigation and Drainage Paper, 56.

Roossinck, M. J. (2002). Evolutionary history of Cucumber mosaic virus deduced by phylogenetic analyses. J. Virol., 76, 3382-3387.

http://dx.doi.org/ 10.1128/JVI.76.7.3382-3387.2002.

Sani, B. M., Oluwasemire, K. O., \& Mohammed, H. I. (2008). Effect of irrigation and plant density on the growth, yield and water use efficiency of early maize in the Nigerian Savanna. ARPN Journal of Agricultural and Biological Science 3(2):33-40. ISBN-1990-6145

Taiwo, M. A., Kareem, K. T., Nsa, I. Y., \& D'A Hughes, J. (2007). Cowpea viruses: effect of single and mixed infections on symptomatology and virus concentration. Virol J, 4, 95. http://dx.doi.org/10.1186/1743-422X-4-95

Untiveros, M., Fuentes, S., Salazar, L. F. (2007). Synergistic interaction of Sweet potato chlorotic stunt virus (Crinivirus) with Carla-, Cucumo-, Ipomo-, and Potyviruses infecting sweet potato. Plant Dis 91, 669-676. http://dx.doi.org/10.1094.PDIS-91-6-0669.

Valli, A. Martin-Hernandez, A. M., Lopez-Moya, J. J.and Garcia, J. A (2006). RNA Silencing Suppression by a second copy of the P1 serine protease of Cucumber Vein YellowingIpomovirus, a member of the family Potyviridae that lacks the cysteine Protease HCPro. J. Virol 80(20): 10055-10063. http://dx.doi.org/10.1128/jvI.00985-06.

Wang, Y., Gaba, V., Yang, J., Palukaitis, P., \& Gal-On, A. (2002). Characterization of synergy between Cucumber mosaic virus and potyviruses in cucurbit hosts. Phytopathology, 92, 51-58. http://dx.doi.org/ 10.1094/mpm1-03-10-0064

Wang, Y., Lee, K. C., Gaba, V., Wong, S. M., Palukaitis, P. Gal-On, A. (2004). Breakage of resistance to Cucumber mosaic virus by co-infection with Zucchini yellow mosaic virus: Enhancement of CMV accumulation independent of symptom 424 expression. Arch Virol, 149, 379-396. http://dx.doi.org/ 10.1007/s00705-003-0240-4

Wege, C., \& Siegmund, D. (2007). Synergism of a DNA and a RNA virus: enhanced tissue infiltration of the begomovirus Abutilon mosaic virus (AbMV) mediated by Cucumber mosaic virus (CMV). Virology, 357, 10-28. http://dx.doi.org/10.1016/j.virol.2006.07.043 


\section{Macrothink}

Journal of Agricultural Studies

ISSN 2166-0379 2016, Vol. 4, No. 3

Wintermantel, W. M., Cortez, A. A., Anchieta, A. G., Gulati-Sakhuja, A. Hladky, L. L. (2008). Co-infection by two criniviruses alters accumulation of each virus in a host-specific manner and influences efficiency of virus transmission. Phytopathology, 98, 1340-1345.

http://dx.doi.org/ 10.1094/phyTO-98-12-1340

Zitter, T. A., \& Murphy, J. F. (2009). Cucumber mosaic virus. The Plant Health Instructor. American Phytopathological Society Net. http://dx.doi.org/10.1094/PHI-I-2009-0518-01.

\section{Copyright Disclaimer}

Copyright for this article is retained by the author(s), with first publication rights granted to the journal.

This is an open-access article distributed under the terms and conditions of the Creative Commons Attribution license (http://creativecommons.org/licenses/by/3.0/). 